\title{
Christian Existentialism
}

\section{Translated by DONALD A. LOWRIE}

An anthology of the works of Nicolai Berdyaev presenting his main ideas on philosophy and the world in general in entirely new translations. Within this single volume the reader has for the first time the thought of one of the most influential thinkers of this century. '. . . deserves a place in the library of every thoughtful Christian.'

Modern Churchman. 55 s.

\section{The Perceptual Process}

\section{A. CAMPBELL GARNETT}

Professor Garnett is well known for his contributions to metaphysics and ethics in the philosophical journals of the United States and Great Britain. In this book he maintains that the task of philosophy is the reflective analysis of mental life. He shows how the analysis of ordinary language can be used as a valuable tool in this. 21 s.

\section{Philosophy in America}

\section{Edited by MAX BLACK}

A collection of twelve original essays on a variety of philosophical topics by some of the most talented younger American philosophers, specially commissioned for this volume, with an introduction by the editor. With contributions from: William P. Alston; Bruce Aune; S. F. Barker; Stanley Cavell; Thompson Clarke; Marshall Cohen; Joel Feinberg; Jerry A. Fodor; Charles D. Parsons; Alvin Plantinga; John Searle; Abner Shimony; Fred Sommers; Judith Jarvis Thompson. 42s.

\section{The Matter of Zen}

\section{PAUL WIENPAHL}

In this book Paul Wienpahl, a Western-schooled philosopher who has studied zazen in Japan, explains the discipline in step-by-step detail. He describes each of the traditional aids to zazen: the lotus position; breathing in a certain way; counting; koans, or puzzles; the role of the roshi, or teacher; and the Zen moral code. 20 s.

\section{ALLEN \& UNWIN}




\section{THE STRUCTURE OF BEHAVIOUR}

\section{Maurice Merleau-Ponty}

\section{Translated by ALDEN L. FISHER}

'The book is pitched at the level of scientific experience and undertakes to prove that this experience itself does not make sense within the ontological perspectives which science spontaneously adopts. With painstaking analysis Merleau-Ponty demonstrates how frequently the very facts which science seeks to elucidate impel it to adopt uncritically assumptions about the lifeworld which it is then (because of its more restricted methods) unable to check.'

Scotsman. 35 s.

\section{WITTGENSTEIN AND MODERN PHILOSOPHY}

\section{Justus Hartnack}

\section{Translated by MAURICE CRANSTON}

A lucid examination of this still very much present and controversial figure, which defines his main position and assesses the considerable influence he has had on Anglo-Saxon philosophy.

21s.

\section{THE ELEMENTS OF FORMAL LOGIC}

\section{G. E. Hughes and D. G. Londey}

A textbook of modern deductive logic expressly designed to make the subject approachable for beginners and to give them a practical training in doing logic for themselves. Exercises are appended to most of the chapters, and answers are provided.

Hardback 36s. University Paperback 21s. 


\section{FOUNDATIONS OF LANGUAGE}

\section{International Journal of Language and Philosophy}

Editorial Board: Morris Halle (MIT), Peter Hartmann (Münster/W), K. Kunjunni Raja (Madras), Benson Mates (Univ. of California), J. F. Staal (Amsterdam),

Pieter A. Verburg (Groningen), John W. M. Verhaar (Manila)

\section{VOLUME I, No. 2, MAY 1965}

Articles. J. F. Staal: E. W. Beth 1908-1963; S. R. Levin: Langue and Parole in American Linguistics; S. Hattori: The Sound and Meaning of Language; R. B. Lees: Turkish Nominalizations and a Problem of Ellipsis; W. Motsch: Grammar and Semantics. Reviews. Emmon Bach: An Introduction to Transformational Grammars (Rudolf de Rijk); Jerrold J. Katz and Paul M. Postal: An Integrated Theory of Linguistic Descriptions (J. F. Staal); Publications Received for Review.

FOUNDATIONS OF LANGUAGE is published quarterly.

Annual subscription price $f 42$.-( $\$ 11,75: 84 \mathrm{~s}$.).

\section{REIDEL PUBLISHING COMPANY/DORDRECHT-HOLLAND}

\section{THE PHILOSOPHICAL QUARTERLY}

Contents of Volume 15, No. 61, October 1965

I. Truth: A Reconsideration of Austin's Views: $P$. F. Strawson

II. Synonymy: $B$. L. Blose

III. Degrees of Knowledge:

Gershon Weiler

IV. Aristotle's Logic of Analogy: Mary Hesse

V. Hobbes, Mechanism, and Egoism: Bernard Gert

VI. Discussions:

Invalidly Invalidating a Paradox: William $\boldsymbol{H}$. Baumer

On Defining 'S knows that P': Douglas Odegard

VII. Book Reviews

VIII. List of Books Received

Edited by G. P. Henderson with the assistance of Roland Hall, and published for the Scots Philosophical Club by the University of St Andrews.

Price twenty-five shillings per annum (in U.S.A. $\$ 4.00$ ), post free, for orders placed directly with the Treasurer (Miss J. S. M. Allan, The University, St Andrews, Scotland) or the Assistant Treasurer (Prof. V. C. versity of Chicamo, Chicaso 37, Illinois, versity of Chicago, Chicago 37, Illinois,
U.S.A.). For orders placed through bookcellers or agents the price is thirty shillings per annum (in U.S.A. $\$ 5.00$ ).

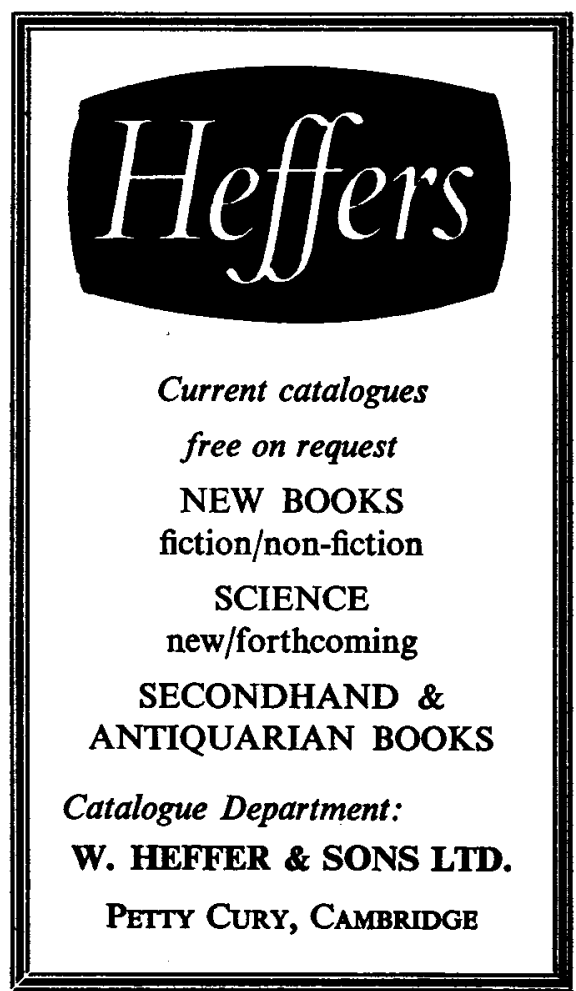




\section{St. Anselm's 'Proslogion'}

with $A$ Reply on Behalf of the Fool by Gaunilo and The Author's Reply to Gaunilo Translated with an introduction and philosophical commentary by M. J. CHARLESWORTH

An introduction makes clear St Anselm's purpose, and a philosophical commentary analyses the three texts and points their contemporary relevance. 35 s net

\section{The Philosophy of Hegel}

\section{G. R. G. MURE}

An outline of the principles governing Hegel's mature thinking and a description of the Hegelian system in its own order. 1 table. $12 s 6 d$ net (Home University Library)

\section{Elementary Logic}

\section{BENSON MATES}

The author defines each of the principles involved before describing the grammar and semantics of a fairly simple artificial language. $42 s$ net

\section{OXFORD \\ UNIVERSITY PRESS}

\section{University of Melbourne}

\section{Lecturer}

\section{in the \\ DEPARTMENT OF PHILOSOPHY}

Applications are invited for the above-mentioned position.

Qualifications: Honours degree (or the equivalent).

DurIEs: Teaching and research. Applicants should be qualified to lecture in logic.

SALARY: $£ A 2,400$ to $£ A 3,150$.

Initial salary will be determined according to qualifications and experience.

Further information including details of F.S.S.U. type superannuation, travel and removal expenses, housing assistance and conditions of appointment is available from the Association of Commonwealth Universities (Branch Office), Marlborough House, Pall Mall, London, S.W.1.

Applications close in Australia and London on 1 st November 1965.

\section{THE AUSTRALASIAN JOURMAL OF PHILOSOPHY}

Edited by A. K. Srout

ARticles:

Nort Flaming: The idea of a solid.

ROGER Montague: 'Ought' from 'is'.

F. M. CoHEN: Knowledge and moral belief. IRVING BLOCK: On the 'commonness' of the common sensibles.

ROBERT SAMRK: Performative utterances and the concept of contract.

\section{Discussion:}

Allan F. Grbbard: Rule-utilitarianism: merely an illusory alternative?

JosEPH MARGOLIS: Rule utilitarianism.

GERTRUde EYORSKY: Utilitarianism and rules.

JAMES CARGRE: The universalisability of lying.

REVIEWS, BOOKS RECEIVED.

Vol. 43 AUGust 1965

No. 2

Published in May, August and December: Annual Subscription $£ 1$ 2s. Sterling ( $£ 1$ to members of the Australasian Association of Philosophy, which you are invited to join). A Philosophy, which you are invited to join). A
sample copy and other information may be sample copy and other information may be University of Sydney, N.S.W. 